\title{
Synthesis of a "Masked" Terminal Nickel(II) Sulfide via Reductive Deprotection and its Reaction with Nitrous Oxide
}

\author{
Nathaniel J. Hartmann, Guang Wu, and Trevor W. Hayton ${ }^{*}$ \\ ${ }^{*}$ N. J. Hartmann, Dr. G. Wu, Prof. Dr. T. W. Hayton, Department of Chemistry and Biochemistry, \\ University of California Santa Barbara, Santa Barbara, CA 93106, hayton@chem.ucsb.edu
}

\begin{abstract}
Addition of 1 equiv of $\mathrm{KSCPh}_{3}$ to $\left[\mathrm{L}^{\mathrm{R}} \mathrm{NiCl}\right]\left(\mathrm{L}^{\mathrm{R}}=\left\{\left(2,6-{ }^{\mathrm{i}} \mathrm{Pr}_{2} \mathrm{C}_{6} \mathrm{H}_{3}\right) \mathrm{NC}(\mathrm{R})\right\}_{2} \mathrm{CH}, \mathrm{R}=\mathrm{Me},{ }^{\mathrm{t}} \mathrm{Bu}\right)$ in $\mathrm{C}_{6} \mathrm{H}_{6}$ results in the formation of $\left[\mathrm{L}^{\mathrm{R}} \mathrm{Ni}\left(\mathrm{SCPh}_{3}\right)\right]\left(\mathbf{1}, \mathrm{R}=\mathrm{Me} ; \mathbf{2}, \mathrm{R}={ }^{\mathrm{t}} \mathrm{Bu}\right)$ in good yields.

Subsequent reduction of $\mathbf{1}$ and $\mathbf{2}$ with 2 equiv of $\mathrm{KC}_{8}$, in cold $\left(-25^{\circ} \mathrm{C}\right) \mathrm{Et}_{2} \mathrm{O}$, in the presence of 2 equiv of 18 -crown-6, results in the formation of "masked" terminal $\mathrm{Ni}^{\mathrm{II}}$ sulfides, [K(18-crown-6)] $\left[\mathrm{L}^{\mathrm{R}} \mathrm{Ni}(\mathrm{S})\right]\left(\mathbf{3}, \mathrm{R}=\mathrm{Me} ; \mathbf{4}, \mathrm{R}={ }^{\mathrm{t}} \mathrm{Bu}\right)$, also in good yields. An X-ray crystallographic analysis of these complexes suggests that they feature partial multiple bond character in their Ni-S linkages. Addition of $\mathrm{N}_{2} \mathrm{O}$ to a toluene solution of $\mathbf{4}$ provides [K(18-crown-6)] [ $\left.\mathrm{L}^{\mathrm{tBu}} \mathrm{Ni}(\mathrm{SN}=\mathrm{NO})\right](\mathbf{6})$, which features the first example of a thiohyponitrite $\left(\left[\kappa^{2}-\mathrm{SN}=\mathrm{NO}\right]^{2-}\right)$ ligand.
\end{abstract}

\section{Keywords}

Nickel; Nitrogen Oxides; Protecting Group; Sulfide

\begin{abstract}
Metal-ligand multiple bonding in the late metals (groups 9, 10,11) is relatively rare.[1,2] This observation can be rationalized by the "oxo wall" concept,[3] which postulates that a tetragonal complex with a $\mathrm{d}^{5}$ configuration (or greater) cannot form stable multiple bonds because of occupation of the $\mathrm{M}=\mathrm{E} \pi^{*}$ orbitals. While no exceptions to the "oxo wall" concept are currently known, it can be circumvented by reducing the coordination number at the metal center. For example, two late metal oxos have been reported, namely $[\operatorname{Ir}(\mathrm{O})$ $\left.(\mathrm{Mes})_{3}\right]\left(\mathrm{Mes}=2,4,6-\mathrm{Me}_{3} \mathrm{C}_{6} \mathrm{H}_{2}\right)$ and $[\mathrm{Pt}(\mathrm{O})(\mathrm{PCN})]\left(\mathrm{PCN}=\mathrm{C}_{6} \mathrm{H}_{3}\left[\mathrm{CH}_{2} \mathrm{P}(t \mathrm{Bu})_{2}\right]\right.$ $\left(\mathrm{CH}_{2} \mathrm{CH}_{2} \mathrm{NMe}_{2}\right)$ ), and both feature four coordinate geometries.[4,5] Two recently isolated Ir nitride complexes also feature four coordinate geometries.[6,7] Similarly, a handful of isolable cobalt, nickel, and copper nitrenes are known, such as [( $\left.\left.\mathrm{Me}_{2} \mathrm{NN}\right) \mathrm{Co}(\mathrm{NAd})\right]$ $\left(\mathrm{Me}_{2} \mathrm{NN}=\left(\left\{2,6-\mathrm{Me}_{2} \mathrm{C}_{6} \mathrm{H}_{3}\right) \mathrm{NC}(\mathrm{Me})\right\}_{2} \mathrm{CH}\right),\left[(\mathrm{dtbpe}) \mathrm{Ni}\left(\mathrm{N}\left(2,6-{ }^{\mathrm{i}} \mathrm{Pr}_{2} \mathrm{C}_{6} \mathrm{H}_{3}\right)\right](\mathrm{dtbpe}=\right.$ $\left.\mathrm{P}^{\mathrm{t}} \mathrm{Bu}_{2} \mathrm{CH}_{2} \mathrm{CH}_{2} \mathrm{P}^{\mathrm{t}} \mathrm{Bu}_{2}\right)$, [(IPr*) $\mathrm{Ni}\left(\mathrm{N}\left(2,6-(\mathrm{Mes})_{2} \mathrm{C}_{6} \mathrm{H}_{3}\right)\right]$, and [ $\left.\left\{\left(\mathrm{Me}_{3} \mathrm{NN}\right) \mathrm{Cu}\right\}_{2}(\mu-\mathrm{NAd})\right]$ $\left(\mathrm{Me}_{3} \mathrm{NN}=\left\{\left(2,4,6-\mathrm{Me}_{3} \mathrm{C}_{6} \mathrm{H}_{2}\right) \mathrm{NC}(\mathrm{Me})\right\}_{2} \mathrm{CH}\right)$, which also feature low coordination numbers (2-4).[8-11] Also of note are the closely related nickel carbene and phosphinidene complexes, [(dtbpe) $\mathrm{Ni}(\mathrm{E})]\left(\mathrm{E}=\mathrm{CPh}_{2}, \mathrm{P}\left[2,6-\mathrm{Mes}_{2} \mathrm{C}_{6} \mathrm{H}_{3}\right]\right)$, reported by Hillhouse and coworkers. $[12,13]$ This class of materials is highly reactive and is capable of effecting $\mathrm{CO}$ oxidation, $\mathrm{C}-\mathrm{H}$ activation, and [2+2] cycloaddition, demonstrating their utility for small molecule activation.[14-25]
\end{abstract}


In contrast to the above-mentioned success with $\mathrm{C}, \mathrm{O}, \mathrm{N}$, and P-donor multiple bonds, attempts to synthesize a stable late metal terminal sulfide have been unsuccessful. For example, Driess and co-workers postulated that reaction of $\left[\mathrm{L}^{\mathrm{R}} \mathrm{Ni}\left(\eta^{2}-\mathrm{S}_{2}\right)\right]\left(\mathrm{L}^{\mathrm{R}}=\right.$ $\left.\left\{\left(2,6-{ }^{i} \mathrm{Pr}_{2} \mathrm{C}_{6} \mathrm{H}_{3}\right) \mathrm{NC}(\mathrm{R})\right\}_{2} \mathrm{CH}, \mathrm{R}=\mathrm{Me}\right)$ with $\mathrm{Ph}_{3} \mathrm{P}$ resulted in transient formation of [ $\left.\mathrm{L}^{\mathrm{R}} \mathrm{Ni}(\mathrm{S})\right]$, but it rapidly dimerizes to form a bridged disulfide complex.[26] Similarly, Jones and co-workers reported the transient formation of [(dippe)Ni(S)], which could be trapped by a variety of nitrones.[27]

Recently, we reported the synthesis of a $\mathrm{Th}^{\mathrm{IV}}$ sulfide complex, [K(18-crown-6)][Th(S) $\left(\mathrm{NR}_{2}\right)_{3}$ ] $\left(\mathrm{R}=\mathrm{SiMe}_{3}\right)$, via reductive removal of the trityl protecting group.[28] Building on this work, we next attempted to apply this "reductive deprotection" reaction to the synthesis of an isolable late metal terminal sulfide. Herein, we report the synthesis of a "masked" terminal $\mathrm{Ni}^{\mathrm{II}}$ sulfide and describe its reactivity with nitrous oxide.

Addition of 1 equiv of $\mathrm{KSCPh}_{3}$ to $\left[\mathrm{L}^{\mathrm{R}} \mathrm{NiCl}\right]\left(\mathrm{R}=\mathrm{Me},{ }^{\mathrm{t}} \mathrm{Bu}\right)[29]$ in $\mathrm{C}_{6} \mathrm{H}_{6}$ results in the formation of $\left[\mathrm{L}^{\mathrm{R}} \mathrm{Ni}\left(\mathrm{SCPh}_{3}\right)\right]\left(\mathbf{1}, \mathrm{R}=\mathrm{Me} ; \mathbf{2}, \mathrm{R}={ }^{\mathrm{t}} \mathrm{Bu}\right)(\mathrm{Scheme} 1)$. Their formulations were confirmed by elemental analysis and $\mathrm{X}$-ray crystallography (full structural details can be found in the Supporting Information). Moreover, their ${ }^{1} \mathrm{H}$ NMR spectra are similar to those reported for other $\mathrm{Ni}^{\mathrm{II}} \beta$-diketiminate thiolate complexes, such as $\left[\mathrm{L}^{\mathrm{tBu}} \mathrm{Ni}(\mathrm{SPh})\right]$ and $\left[\mathrm{L}^{\mathrm{tBu}} \mathrm{Ni}(\mathrm{SEt})\right] \cdot[30,31]$

Subsequent reduction of $\mathbf{1}$ and $\mathbf{2}$ with 2 equiv of $\mathrm{KC}_{8}$, in cold $\left(-25^{\circ} \mathrm{C}\right) \mathrm{Et}_{2} \mathrm{O}$, in the presence of 2 equiv of 18-crown-6, results in the formation of [K(18-crown-6)][ $\left.\mathrm{L}^{\mathrm{R}} \mathrm{Ni}(\mathrm{S})\right](\mathbf{3}, \mathrm{R}=\mathrm{Me}$; $4, \mathrm{R}={ }^{\mathrm{t}} \mathrm{Bu}$ ). Complex 3 can be isolated as dark green blocks from hexanes $/ \mathrm{C}_{6} \mathrm{H}_{6}$ in $66 \%$ yield, while complex 4 can be isolated as dark brown plates from toluene/isooctane in $88 \%$ yield (Scheme 1). Similarly, use of 2,2,2-cryptand in place of 18-crown-6 affords [K(2,2,2cryptand)][ $\left.\mathrm{L}^{\mathrm{tBu}} \mathrm{Ni}(\mathrm{S})\right](\mathbf{5})$, which can be isolated as brown needles in $89 \%$ yield after crystallization from hexanes (Scheme 1). The syntheses of $\mathbf{3}, \mathbf{4}$, and $\mathbf{5}$ also produce one equiv of $[\mathrm{K}(\mathrm{L})]\left[\mathrm{CPh}_{3}\right](\mathrm{L}=18$-crown-6, 2,2,2-cryptand), which precipitates from the reaction mixtures as a bright red solid that can be separated from the Ni-containing products via filtration (Scheme 1). Interestingly, C-S bond cleavage has been observed previously in a $\mathrm{Ni}$ tritylthiolate complex.[32] For example, Riordan and co-workers reported the formation of $\left[\left\{\mathrm{PhB}\left(\mathrm{CH}_{2} \mathrm{~S}^{\mathrm{t}} \mathrm{Bu}\right)_{3} \mathrm{Ni}\right]_{2}\left(\mu_{2}-\eta^{2}, \eta^{2}-\mathrm{S}_{2}\right)\right.$ and $\cdot \mathrm{CPh}_{3}$ upon thermal decomposition of $\left[\left\{\mathrm{PhB}\left(\mathrm{CH}_{2} \mathrm{~S}^{t} \mathrm{Bu}\right)_{3} \mathrm{Ni}\left(\mathrm{SCPh}_{3}\right)\right]\right.$, however, there is no evidence for the generation of a terminal sulfide in this reaction.

The formulations of complexes 3,4 , and 5 were confirmed through elemental analysis, ${ }^{1} \mathrm{H}$ NMR spectroscopy, and X-ray crystallography. The solid-state structures of $\mathbf{4}$ and $\mathbf{5}$ are shown in Figure 1, while selected metrical parameters can be found in Table 1. Complexes 3, 4 and 5 feature identical coordination environments about their Ni centers. In the solid state, each exhibits a planar $\left(\Sigma(\mathrm{L}-\mathrm{Ni}-\mathrm{L}) \sim 360^{\circ}\right)$, Y-shaped geometry. The Ni-S bond lengths in 3-5 range from 2.0635(6)-2.0843(1) $\AA$. All three complexes feature long S-K interactions, [28,33] which range from 3.094(2)-3.3795(1) ̊.. Not surprisingly, complex 5, which features the strongest $\mathrm{K}^{+}$chelator (2,2,2-cryptand), exhibits the longest $\mathrm{S}-\mathrm{K}$ interaction. Interestingly, the Ni-S-K angles vary widely, from $153.73(3)^{\circ}$ (for 3 ) to $177.9(1)^{\circ}$ (for 4 ), a disparity we ascribe to crystal packing. Also of note, complex 4 exists as 
a dimer in the solid state; its monomer units are connected via bridging interaction between the $\left[\mathrm{K}(18 \text {-crown-6] }]^{+}\right.$cations (Figure 1). Finally, the Ni-N distances in 3-5 are typical of those found in other three coordinate $\mathrm{Ni}^{\mathrm{II}} \beta$-diketiminate complexes.[29-31,34]

The Ni-S bond lengths in complexes $\mathbf{3}, \mathbf{4}$, and $\mathbf{5}$ are amongst the shortest known, and are intermediate between the additive covalent radii projected for nickel-sulfur single (2.13 $\mathrm{A}$ ) and double bonds $\left(1.95 \AA\right.$ A).[23,24,35] For comparison, [ $\left.\left\{\mathrm{L}^{\mathrm{tBu} N i}\right\}_{2}(\mu-\mathrm{S})\right],[30]\left[\{(\mathrm{IPr}) \mathrm{Ni}\}_{2}(\mu-\right.$ $\left.\mathrm{S})_{2}\right]$ (IPr = 1,3-bis(2,6-diisopropylphenyl)imidazol-2-ylidene),[36] and $\left[\left(\mathrm{PhB}\left\{\mathrm{CH}_{2} \mathrm{~S}^{\mathrm{t}} \mathrm{Bu}\right\}_{3}\right) \mathrm{Ni}\right]_{2}(\mu-\mathrm{S}),[32]$ possess comparable Ni-S bond lengths of 2.0651(7), 2.0972(6), and 2.0714(4) $\AA$, respectively, despite each possessing a bridging $S^{2-}$ ligand. Overall, this suggests similar magnitudes of $\pi$-bonding in both classes of materials.

The ${ }^{1} \mathrm{H}$ NMR spectra of complexes 3-5 in $\mathrm{C}_{6} \mathrm{D}_{6}$ are typical of those observed for other three coordinate, high spin $\mathrm{Ni}^{\mathrm{II}} \beta$-diketiminate complexes.[29,34] Notably, the resonances assignable to the $\left[\mathrm{K}(18 \text {-crown-6) }]^{+}\right.$cations are broad and shifted to 1.18 and $0.28 \mathrm{ppm}$ for 3 and $\mathbf{4}$, respectively. The 2,2,2,-cryptand resonances for $\mathbf{5}$ are similarly broadened and shifted. These data suggest that the $[\mathrm{K}(\mathrm{L})]^{+}$cations form a contact pair with the $\left[\mathrm{L}^{\mathrm{R}} \mathrm{Ni}(\mathrm{S})\right]^{-}$ anions in solution. In the solid state, complexes $\mathbf{3}$ and $\mathbf{4}$ exhibit effective magnetic moments of 2.80 B.M. at $300 \mathrm{~K}\left(D=91 \mathrm{~cm}^{-1}\right)$ and 2.98 B.M. at $300 \mathrm{~K}\left(D=94 \mathrm{~cm}^{-1}\right)$, respectively (Figures S22, S23). This behavior is consistent with that anticipated for a Y-shaped $\mathrm{Ni}^{\mathrm{II}}$ complex with an $S=1$ ground state.[37] Overall, the solid state molecular structures and magnetic properties of 3-5 confirm our $\mathrm{Ni}^{\mathrm{II}}$ oxidation state assignments, and exclude the possibility that the sulfur atom is protonated, as this would require nickel to be in the +1 oxidation state. Intriguingly, the related $\mathrm{Ni}^{\mathrm{II}}$ imido, carbene, and phosphinidene complexes, e.g., $[(\mathrm{dtbpe}) \mathrm{Ni}(\mathrm{E})]$, are diamagnetic. $[9,12,13]$ This change in spin state may reflect differing amounts of $\pi$-bonding between the two classes of molecules.

The combined characterization data for complexes 3-5 reveal that the S-K interaction is conserved in both solution and the solid state. However, preliminary reactivity data suggest that the S-K interaction is quite labile, permitting these complexes to behave as "masked" terminal sulfides.[38] For example, exposure of complex 4 to an atmosphere of nitrous oxide $\left(\mathrm{N}_{2} \mathrm{O}\right)$ results in a rapid color change from dark brown to yellow. Isolation of the resulting product via crystallization from toluene/isooctane provides [K(18-crown-6)] $\left[\mathrm{L}^{\mathrm{tBu}} \mathrm{Ni}(\mathrm{SN}=\mathrm{NO})\right](6)$ as an orange crystalline solid in $62 \%$ yield (eq 1). Complex 6 crystallizes in the triclinic space group $P-1$, and its solid state molecular structure is shown in Figure 2. Complex 6 features an unprecedented $\kappa^{2}$-thiohyponitrite $\left([\mathrm{SN}=\mathrm{NO}]^{2-}\right)$ ligand, formed by [3+2] cycloaddition of $\mathrm{N}_{2} \mathrm{O}$ across the Ni-S bond. The $\mathrm{S}-\mathrm{N}$ and $\mathrm{O}-\mathrm{N}$ distances in the $[\mathrm{SN}=\mathrm{NO}]^{2-}$ moiety are 1.787(6) $\AA$ and 1.308(1) $\AA$, respectively, and are suggestive of single bonds, while the N-N bond length of 1.154(9) $\AA$ is indicative of a double bond. These parameters are consistent with the presence of a dianionic hyponitrite moiety, which, in combination with the diamagnetism of $\mathbf{6}$, as revealed by its ${ }^{1} \mathrm{H}$ NMR spectrum (see SI), is consistent with the anticipated $\mathrm{Ni}^{\mathrm{II}}$ oxidation state assignment.

Complex $\mathbf{6}$ is a rare example of a structurally characterized transition metal complex containing activated $\mathrm{N}_{2} \mathrm{O}$ and features the first example of a thiohyponitrite $\left(\left[\kappa^{2}-\mathrm{SN}=\mathrm{NO}\right]^{2-}\right)$ ligand. Its formation is reminiscent of the Frustrated Lewis Pair (FLP) systems, ${ }^{t} \mathrm{Bu}_{3} \mathrm{P} /$ 
$\mathrm{B}\left(\mathrm{C}_{6} \mathrm{~F}_{5}\right)_{3}$ and $\left[\left\{\left(\mathrm{C}_{6} \mathrm{H}_{4}\right)_{2}(\mathrm{O}) \mathrm{CMe}_{2}\right\}\left(\mathrm{PMes}_{2}\right)\left(\mathrm{B}\left(\mathrm{C}_{6} \mathrm{~F}_{5}\right)_{2}\right)\right]$, which react with $\mathrm{N}_{2} \mathrm{O}$ to form $\left[{ }^{\mathrm{t} B u_{3}} \mathrm{P}(\mathrm{N}=\mathrm{NO}) \mathrm{B}\left(\mathrm{C}_{6} \mathrm{~F}_{5}\right)_{3}\right][39]$ and $\left[\left\{\left(\mathrm{C}_{6} \mathrm{H}_{4}\right)_{2}(\mathrm{O}) \mathrm{CMe}_{2}\right\}\left(\mathrm{PMes}_{2}\right)(\mathrm{N}=\mathrm{NO})\left(\mathrm{B}\left(\mathrm{C}_{6} \mathrm{~F}_{5}\right)_{2}\right)\right][40]$ respectively, or the reaction of $\mathrm{N}_{2} \mathrm{O}$ with $\mathrm{Na}_{2} \mathrm{O}$, which results in formation of trans$\left[\mathrm{Na}_{2} \mathrm{~N}_{2} \mathrm{O}_{2}\right]$.[41,42] Also relevant is the reaction of IPr with $\mathrm{N}_{2} \mathrm{O}$ to form IPr- $\mathrm{N}_{2} \mathrm{O}$.[43] These results support the conclusion that the $[\mathrm{SN}=\mathrm{NO}]^{2-}$ ligand is formed by nucleophilic attack of $\mathrm{N}_{2} \mathrm{O}$ by the sulfide ligand in $4 \cdot[39,43,44]$

In summary, cleavage of the $\mathrm{C}-\mathrm{S}$ bond in $\left[\mathrm{L}^{\mathrm{R}} \mathrm{Ni}\left(\mathrm{SCPh}_{3}\right)\right]$ by reductive deprotection allows access to a family of "masked" terminal $\mathrm{Ni}^{\mathrm{II}}$ sulfides, namely $[\mathrm{K}(\mathrm{L})]\left[\left(\mathrm{L}^{\mathrm{R}}\right) \mathrm{Ni}(\mathrm{S})\right]$. The $\mathrm{Ni}-\mathrm{S}$ distances in this class of materials are amongst the shortest observed, suggesting the presence of partial multiple bond character. $\left[\mathrm{K}\left(18\right.\right.$-crown-6)][( $\left.\left.\mathrm{L}^{\mathrm{tBu}}\right) \mathrm{Ni}(\mathrm{S})\right]$ reacts with $\mathrm{N}_{2} \mathrm{O}$ to form a novel thio-hyponitrite complex, [K(18-crown-6)][ $\left.\mathrm{L}^{\mathrm{tBu}} \mathrm{Ni}(\mathrm{SN}=\mathrm{NO})\right]$, confirming the lability of the S-K interaction. Going forward, we will continue to explore the small molecule reactivity of this class of complexes. In addition, we will target the synthesis of their oxygen congeners.

\section{Supplementary Material}

Refer to Web version on PubMed Central for supplementary material.

\section{Acknowledgments}

We thank the National Science Foundation (CHE 1361654) for financial support of this work. This research made use of the SQUID Magnetometer of the Materials Research Laboratory, an NSF MRSEC (DMR 1121053), and the $400 \mathrm{MHz}$ NMR Spectrometer of the Chemistry Department, an NIH SIG (1S10OD012077-01A1).

\section{References}

1. Berry JF. Comments Inorg Chem. 2009; 30:28.

2. Ray K, Heims F, Pfaff FF. Eur J Inorg Chem. 2013:3784.

3. Winkler J, Gray H. Struct Bond. 2012; 142:17.

4. Hay-Motherwell RS, Wilkinson G, Hussain-Bates B, Hursthouse MB. Polyhedron. 1993; 12:2009.

5. Poverenov E, Efremenko I, Frenkel AI, Ben-David Y, Shimon LJW, Leitus G, Konstantinovski L, Martin JML, Milstein D. Nature. 2008; 455:1093.

6. Schöffel J, Rogachev AY, DeBeer George S, Burger P. Angew Chem Int Ed. 2009; 48:4734. Angew. Chem. 2009, 121, 4828.

7. Scheibel MG, Askevold B, Heinemann FW, Reijerse EJ, de Bruin B, Schneider S. Nat Chem. 2012; 4:552. [PubMed: 22717440]

8. Dai X, Kapoor P, Warren TH. J Am Chem Soc. 2004; 126:4798. [PubMed: 15080682]

9. Mindiola DJ, Hillhouse GL. J Am Chem Soc. 2001; 123:4623. [PubMed: 11457258]

10. Laskowski CA, Miller AJM, Hillhouse GL, Cundari TR. J Am Chem Soc. 2011; 133:771. [PubMed: 21175213]

11. Badiei YM, Dinescu A, Dai X, Palomino RM, Heinemann FW, Cundari TR, Warren TH. Angew Chem Int Ed. 2008; 47:9961. Angew. Chem. 2008, 120, 10109.

12. Mindiola DJ, Hillhouse GL. J Am Chem Soc. 2002; 124:9976. [PubMed: 12188647]

13. Melenkivitz R, Mindiola DJ, Hillhouse GL. J Am Chem Soc. 2002; 124:3846. [PubMed: 11942818]

14. Jenkins DM, Betley TA, Peters JC. J Am Chem Soc. 2002; 124:11238. [PubMed: 12236716]

15. Shay DT, Yap GPA, Zakharov LN, Rheingold AL, Theopold KH. Angew Chem Int Ed. 2006; 45:7870. Angew. Chem. 2006, 117, 1532. 
16. Jones C, Schulten C, Rose RP, Stasch A, Aldridge S, Woodul WD, Murray KS, Moubaraki B, Brynda M, La Macchia G, Gagliardi L. Angew Chem Int Ed. 2009; 48:7406. Angew. Chem. 2009, $121,7542$.

17. King ER, Sazama GT, Betley TA. J Am Chem Soc. 2012; 134:17858. [PubMed: 23043624]

18. Mehn MP, Brown SD, Jenkins DM, Peters JC, Que L. Inorg Chem. 2006; 45:7417. [PubMed: 16933946]

19. Mindiola DJ, Waterman R, Iluc VM, Cundari TR, Hillhouse GL. Inorg Chem. 2014; 53:13227. [PubMed: 25437507]

20. Cundari TR, Jimenez-Halla JOC, Morello GR, Vaddadi S. J Am Chem Soc. 2008; 130:13051. [PubMed: 18771265]

21. Pierpont AW, Cundari TR. Inorg Chem. 2010; 49:2038. [PubMed: 19697950]

22. Iluc VM, Hillhouse GL. J Am Chem Soc. 2010; 132:15148. [PubMed: 20929225]

23. Iluc VM, Hillhouse GL. J Am Chem Soc. 2014; 136:6479. [PubMed: 24716462]

24. Iluc VM, Miller AJM, Anderson JS, Monreal MJ, Mehn MP, Hillhouse GL. J Am Chem Soc. 2011; 133:13055. [PubMed: 21797224]

25. Kogut E, Wiencko HL, Zhang L, Cordeau DE, Warren TH. J Am Chem Soc. 2005; 127:11248. [PubMed: 16089446]

26. Yao S, Milsmann C, Bill E, Wieghardt K, Driess M. J Am Chem Soc. 2008; 130:13536. [PubMed: 18803388]

27. Vicic DA, Jones WD. J Am Chem Soc. 1999; 121:4070.

28. Smiles DE, Wu G, Kaltsoyannis N, Hayton TW. Chem Sci. 2015; 6:3891.

29. Holland PL, Cundari TR, Perez LL, Eckert NA, Lachicotte RJ. J Am Chem Soc. 2002; 124:14416. [PubMed: 12452717]

30. Holze P, Horn B, Limberg C, Matlachowski C, Mebs S. Angew Chem Int Ed. 2014; 53:2750. Angew. Chem. 2014, 126, 2788.

31. Horn B, Limberg C, Herwig C, Braun B. Inorg Chem. 2014; 53:6867. [PubMed: 24914615]

32. Cho J, Van Heuvelen KM, Yap GPA, Brunold TC, Riordan CG. Inorg Chem. 2008; 47:3931. [PubMed: 18410087]

33. Smiles DE, Wu G, Hayton TW. J Am Chem Soc. 2014; 136:96. [PubMed: 24350685]

34. Eckert NA, Bones EM, Lachicotte RJ, Holland PL. Inorg Chem. 2003; 42:1720. [PubMed: 12611544]

35. Pyykkö P. J Phys Chem A. 2015; 119:2326. [PubMed: 25162610]

36. Olechnowicz F, Hillhouse GL, Jordan RF. Inorg Chem. 2015; 54:2705. [PubMed: 25742125]

37. Laskowski CA, Morello GR, Saouma CT, Cundari TR, Hillhouse GL. Chem Sci. 2013; 4:170.

38. Mindiola DJ. Angew Chem Int Ed. 2008; 47:1557. Angew. Chem. 2008, 120, 1580.

39. Otten E, Neu RC, Stephan DW. J Am Chem Soc. 2009; 131:9918. [PubMed: 19569691]

40. Mo Z, Kolychev EL, Rit A, Campos J, Niu H, Aldridge S. J Am Chem Soc. 2015 ASAP Article. 41. Feldmann C, Jansen M. Angew Chem Int Ed. 1996; 35:1728. Angew. Chem. 1996, 108, 1807.

42. Wright AM, Hayton TW. Inorg Chem. 2015 ASAP Article.

43. Tskhovrebov AG, Solari E, Wodrich MD, Scopelliti R, Severin K. Angew Chem Int Ed. 2012; 51:232. Angew. Chem. 2012, 124, 236.

44. Yu H, Jia G, Lin Z. Organometallics. 2008; 27:3825. 

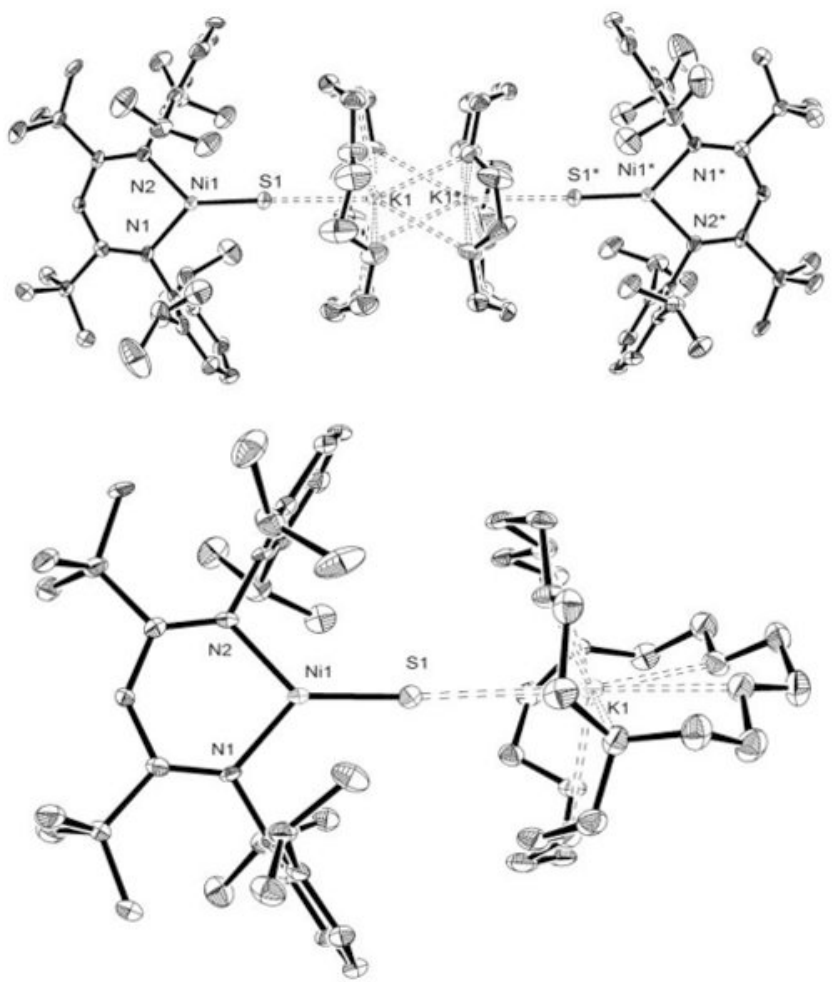

Figure 1.

ORTEP drawings of $\left[\mathrm{K}\left(18\right.\right.$-crown-6)][ $\left.\mathrm{L}^{\mathrm{tBu}} \mathrm{Ni}(\mathrm{S})\right]\left(\mathbf{4} \cdot \mathrm{C}_{8} \mathrm{H}_{18}\right)$ (top) and [K(2,2,2-cryptand)] $\left[\mathrm{L}^{\mathrm{tBu}} \mathrm{Ni}(\mathrm{S})\right](5)$ (bottom) shown with $50 \%$ thermal ellipsoids. Hydrogen atoms and $\mathrm{C}_{8} \mathrm{H}_{18}$ solvate molecule have been omitted for clarity. 

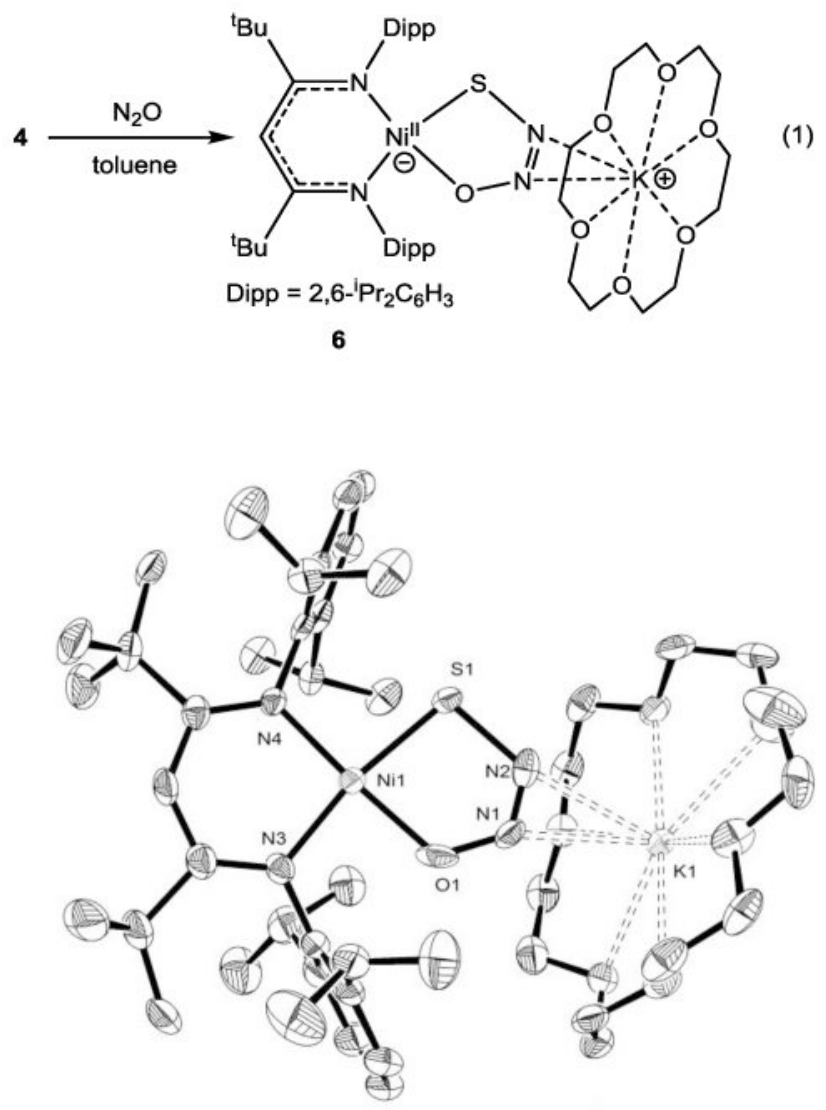

Figure 2.

ORTEP drawing of $\left[\mathrm{K}\left(18\right.\right.$-crown-6)][ $\left.\mathrm{L}^{\mathrm{tBu}} \mathrm{Ni}\left(\kappa^{2}-\mathrm{SN}=\mathrm{NO}\right)\right]\left(6 \cdot 1.5 \mathrm{C}_{7} \mathrm{H}_{8} \cdot 0.5 \mathrm{C}_{8} \mathrm{H}_{18}\right)$ shown with $50 \%$ thermal ellipsoids. Hydrogen atoms and $\mathrm{C}_{7} \mathrm{H}_{8}$ and $\mathrm{C}_{8} \mathrm{H}_{18}$ solvate molecules have been omitted for clarity. 

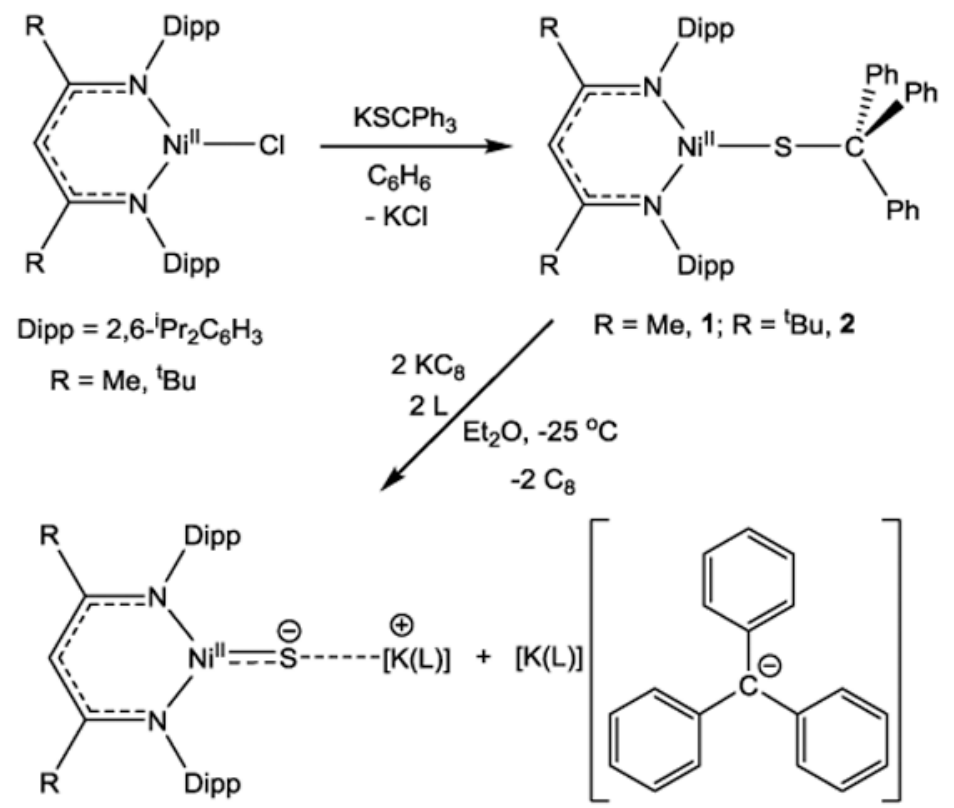

$\mathrm{R}=\mathrm{Me}, \mathrm{L}=$ 18-crown-6, 3;

$\mathrm{R}={ }^{\mathrm{t}} \mathrm{Bu}, \mathrm{L}=18-\mathrm{crown}-6,4$;

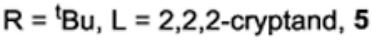

Scheme 1.

Syntheses of complexes 1-5. 


\section{Table 1}

Selected Bond Lengths and Angles for the Nickel(II) Sulfide Complexes 3, 4, and 5.

\begin{tabular}{llll}
\hline bond $(\mathbf{\AA}) /$ angle $\left(^{\circ}\right)$ & $\mathbf{3}$ & $\mathbf{4}$ & $\mathbf{5}$ \\
\hline Ni1-S1 & $2.0635(6)$ & $2.0643(2)$ & $2.0843(1)$ \\
S1-K1 & $3.1212(7)$ & $3.094(1)$ & $3.3795(1)$ \\
Ni-N (av.) & 1.94 & 1.93 & 1.93 \\
Ni1-S1-K1 & $153.74(3)$ & $177.95(8)$ & $170.08(5)$ \\
\hline
\end{tabular}

i1-S1-K1 